\title{
Genes Regulate Blood Pressure, but "Environments" Cause Hypertension
}

\author{
Lin-dan $\mathrm{Ji}^{1,2}$, Nelson L. S. Tang ${ }^{3,4}$, Zhi-feng $X u^{5}$ and Jin $X u^{2,6 *}$ \\ ${ }^{1}$ Department of Biochemistry, School of Medicine, Ningbo University, Ningbo, China, ${ }^{2}$ Zhejiang Key Laboratory of \\ Pathophysiology, Medical School of Ningbo University, Ningbo, China, ${ }^{3}$ Department of Chemical Pathology, Faculty of \\ Medicine, The Chinese University of Hong Kong, Hong Kong, China, ${ }^{4}$ Laboratory for Genetics of Disease Susceptibility, Li Ka \\ Shing Institute of Health Sciences, The Chinese University of Hong Kong, Hong Kong, China, ${ }^{5}$ Department of Cardiology, \\ Ningbo No. 7 Hospital, Ningbo, China, ${ }^{6}$ Department of Preventive Medicine, School of Medicine, Ningbo University, Ningbo, \\ China
}

Keywords: hypertension, blood pressure, single nucleotide polymorphism, environment, gene

\section{INTRODUCTION}

Hypertension is among the first traits studied using genome-wide association study (GWAS). At first, GWAS by the Well-come Trust Case Control Consortium in 2007 did not identify any genome-wide significant single nucleotide polymorphism (SNP) (The Wellcome Trust Case Control Consortium, 2007), however, it was still asserted that GWAS would open the door to find the "missing heritability" of hypertension. In the following years, GWASs of hypertension were still unsuccessful in identifying robust loci until 2009. After shifting attention to the underlying quantitative traits (systolic blood pressure and diastolic blood pressure) and application of GWA meta-analyses of multiple cohorts to enlarge the sample size, the Global Blood Pressure Genetics (Global BPgen) Consortium and the Cohorts for Heart and Aging Research in Genome Epidemiology (CHARGE) Consortium identified 13 genome-wide significant signals (Levy et al., 2009; Newton-Cheh et al., 2009), although these SNPs had very small effect sizes and accounted for $<0.2 \%$ of the overall blood pressure variation in the study populations.

\section{WILL GWAS UNLOCK THE GENETIC BASIS OF HYPERTENSION?}

There was a heated debate in HYPERTENSION on December 2010. Dominiczak and Munroe described the successes of aforementioned two studies, and predicted a bright future for GWAS in hypertension (Dominiczak and Munroe, 2010). On the contrary, Kurtz contended that GWAS had failed, and would continue to fail, to delineate the genetic basis of hypertension. He suggested that efforts and dollars should be shifted to other strategies and technologies that may hold greater chance for advancing our understanding of the genetic etiology of hypertension (Kurtz, 2010). Despite different opinions, both pro and con sides shared some common ground: lowfrequency/rare variants are important, and the sample size should be further enlarged.

In 2016, three large-scale GWASs of hypertension were published in NATURE GENETICS (Ehret et al., 2016; Liu et al., 2016; Surendran et al., 2016). After applying newly designed microarray chips and meta-analyses of multiethnic populations with unprecedented large sample sizes $(>300,000)$, these studies identified several new common loci of modest effects, and provided insights into the impact of low-frequency/rare variants. Subsequently, other genome-wide analyses of blood pressure traits (systolic, diastolic, and pulse pressure) were carried out in people of European ancestry drawn from UK Biobank (UKB), the International Consortium of Blood Pressure Genome Wide Association Studies (ICBP), the Genetic Epidemiology Research on Adult Health and Aging (GERA) cohort, and other combined cohorts with very large sample size (Hoffmann et al., 2017; Warren et al., 2017; Evangelou et al., 2018). These studies identified 
TABLE 1 | GWASs for hypertension or blood pressure published in NATURE GENETICS since 2007.

\begin{tabular}{|c|c|c|c|c|c|}
\hline PMID & Year & Disease/trait & Initial sample size & Replication sample size & Major finding \\
\hline 19430479 & 2009 & $\begin{array}{l}\text { DBP, } \\
\text { SBP, HT }\end{array}$ & $\begin{array}{l}29,136 \text { European ancestry } \\
\text { individuals }\end{array}$ & $\begin{array}{l}\text { 34,433 European ancestry } \\
\text { individuals }\end{array}$ & $\begin{array}{l}\text { They identified } 13 \text { SNPs for SBP, } 20 \text { for DBP, } \\
\text { and } 10 \text { for hypertension. }\end{array}$ \\
\hline 19430483 & 2009 & $\begin{array}{l}\text { DBP, } \\
\text { SBP }\end{array}$ & $\begin{array}{l}34,433 \text { European ancestry } \\
\text { individuals }\end{array}$ & $\begin{array}{l}\text { Up to } 100,347 \text { European ancestry } \\
\text { individuals, up to } 12,889 \text { Indian } \\
\text { Asian ancestry individuals }\end{array}$ & $\begin{array}{l}\text { They identified association between systolic or } \\
\text { diastolic blood pressure and common variants } \\
\text { in eight regions near the CYP17A1, CYP1A2, } \\
\text { FGF5, SH2B3, MTHFR, c10orf107, ZNF652, } \\
\text { and PLCD3 genes. }\end{array}$ \\
\hline 21572416 & 2011 & $\mathrm{BP}$ & $\begin{array}{l}\text { 19,608 East Asian ancestry } \\
\text { individuals }\end{array}$ & $\begin{array}{l}30,765 \text { East Asian ancestry } \\
\text { individuals }\end{array}$ & $\begin{array}{l}\text { They identified genome-wide significant } \\
\text { associations with SBP or DBP, which included } \\
\text { variants at four new loci (ST7L-CAPZA1, } \\
\text { FIGN-GRB14, ENPEP, and NPR3) and a newly } \\
\text { discovered variant near TBX3. }\end{array}$ \\
\hline 21909110 & 2011 & PP & $\begin{array}{l}74,064 \text { European ancestry } \\
\text { individuals }\end{array}$ & $\begin{array}{l}48,607 \text { European ancestry } \\
\text { individuals }\end{array}$ & $\begin{array}{l}\text { They identified at genome-wide significance } \\
\text { four new PP loci (at 4q12 near CHIC2, 7q22.3 } \\
\text { near PIK3CG, 8q24.12 in NOV and 11q24.3 } \\
\text { near ADAMTS8), two new MAP loci (3p21.31 } \\
\text { in MAP4 and 10q25.3 near ADRB1) and one } \\
\text { locus associated with both of these traits } \\
\text { (2q24.3 near FIGN). }\end{array}$ \\
\hline 26390057 & 2015 & $\begin{array}{l}\text { DBP, } \\
\text { SBP, PP }\end{array}$ & $\begin{array}{l}\text { 31,516 East Asian ancestry } \\
\text { individuals, 35,352 European } \\
\text { ancestry individuals, 33,126 } \\
\text { South Asian ancestry } \\
\text { individuals }\end{array}$ & $\begin{array}{l}87,205 \text { individuals, 48,268 East } \\
\text { Asian ancestry individuals, 68,456 } \\
\text { European ancestry individuals, } \\
\text { 16,328 South Asian ancestry } \\
\text { individuals }\end{array}$ & $\begin{array}{l}\text { They identified genetic variants at } 12 \text { new loci } \\
\text { to be associated with blood pressure. }\end{array}$ \\
\hline 27618447 & 2016 & $\begin{array}{l}\text { DBP, } \\
\text { SBP, PP, } \\
\text { HT }\end{array}$ & $\begin{array}{l}\text { Up to } 165,276 \text { European } \\
\text { ancestry individuals, up to } \\
27,487 \text { South Asian ancestry } \\
\text { individuals }\end{array}$ & $\begin{array}{l}\text { Up to } 125,713 \text { European ancestry } \\
\text { individuals, up to } 2,641 \text { South } \\
\text { Asian ancestry individuals, } 4,632 \\
\text { Hispanic individuals, } 22,077 \\
\text { African American individuals }\end{array}$ & $\begin{array}{l}\text { They identified } 30 \text { new blood pressure- or } \\
\text { hypertension-associated genetic regions in the } \\
\text { general population, including } 3 \text { rare missense } \\
\text { variants in RBM } 47, \text { COL } 21 A 1 \text { and RRAS with } \\
\text { larger effects than common variants. }\end{array}$ \\
\hline 27618448 & 2016 & $\begin{array}{l}\text { DBP, } \\
\text { SBP, PP, } \\
\text { HT }\end{array}$ & $\begin{array}{l}\text { 120,473 European ancestry } \\
\text { individuals, } 21,503 \text { African } \\
\text { American individuals, } 4,586 \\
\text { Hispanic individuals }\end{array}$ & $\begin{array}{l}\text { 154,543 European ancestry } \\
\text { individuals, } 26,183 \text { South Asian } \\
\text { ancestry individuals }\end{array}$ & $\begin{array}{l}\text { They identified } 31 \text { new blood } \\
\text { pressure-associated loci. }\end{array}$ \\
\hline 27618452 & 2016 & $\begin{array}{l}\text { DBP, } \\
\text { SBP }\end{array}$ & $\begin{array}{l}\text { Up to } 201,529 \text { European } \\
\text { ancestry individuals }\end{array}$ & $\begin{array}{l}\text { Up to } 140,886 \text { European ancestry } \\
\text { individuals }\end{array}$ & $\begin{array}{l}\text { They identified } 66 \text { blood pressure-associated } \\
\text { loci, of which } 17 \text { were new; } 15 \text { harbored } \\
\text { multiple distinct association signals. }\end{array}$ \\
\hline 27841878 & 2016 & $\begin{array}{l}\text { DBP, } \\
\text { SBP, PP }\end{array}$ & $\begin{array}{l}\text { 295,529 European ancestry } \\
\text { individuals, 8,231 Latino } \\
\text { individuals, 3,058 African } \\
\text { American individuals, 2,029 } \\
\text { African British individuals, } \\
\text { 7,701 East Asian ancestry } \\
\text { individuals, 2,735 South Asian } \\
\text { ancestry individuals, 1,979 } \\
\text { mixed and unknown ancestry } \\
\text { individuals }\end{array}$ & NA & $\begin{array}{l}\text { They identified } 39 \text { new loci among } 75 \\
\text { genome-wide significant loci. }\end{array}$ \\
\hline 28135244 & 2017 & $\begin{array}{l}\text { DBP, } \\
\text { SBP, PP }\end{array}$ & $\begin{array}{l}\text { 140,886 European ancestry } \\
\text { individuals }\end{array}$ & $\begin{array}{l}\text { 190,318 European ancestry } \\
\text { individuals }\end{array}$ & $\begin{array}{l}\text { They identified } 107 \text { blood pressure-associated } \\
\text { loci. }\end{array}$ \\
\hline 29403010 & 2018 & $\begin{array}{l}\text { DBP, } \\
\text { SBP, PP }\end{array}$ & $\begin{array}{l}\text { 136,615 Japanese ancestry } \\
\text { individuals }\end{array}$ & NA & $\begin{array}{l}\text { They identified 1,407 trait-associated loci, } 679 \\
\text { of which were novel. }\end{array}$ \\
\hline 30224653 & 2018 & $\begin{array}{l}\text { DBP, } \\
\text { SBP, PP }\end{array}$ & $\begin{array}{l}757,601 \text { European ancestry } \\
\text { individuals }\end{array}$ & $\begin{array}{l}249,262 \text { European ancestry } \\
\text { individuals }\end{array}$ & They identify 535 novel blood pressure loci. \\
\hline 30578418 & 2019 & $\begin{array}{l}\text { DBP, } \\
\text { SBP, PP }\end{array}$ & $\begin{array}{l}\text { 365,998 European ancestry } \\
\text { individuals, 63,490 African } \\
\text { ancestry individuals, 22,802 } \\
\text { Hispanic individuals, 4,792 } \\
\text { Asian ancestry individuals, } \\
\text { 2,695 Native American } \\
\text { ancestry individuals }\end{array}$ & $\begin{array}{l}299,024 \text { European ancestry } \\
\text { individuals, } 17,277 \text { individuals }\end{array}$ & $\begin{array}{l}\text { They discovered } 208 \text { novel common blood } \\
\text { pressure SNPs and } 53 \text { rare variants. }\end{array}$ \\
\hline
\end{tabular}

BP, blood pressure; DBP, diastolic blood pressure; SBP, systolic blood pressure; PP, pulmonary pressure; HT, hypertension. 
hundreds of novel blood pressure loci that offer new biological insights into blood pressure regulation. Also, trans-ethnic genome-wide association study of blood pressure in up to 776,078 participants from the Million Veteran Program (MVP) and collaborating studies discovered 208 novel common blood pressure SNPs and 53 rare variants (Giri et al., 2019). Table 1 listed all high quality GWASs for hypertension or blood pressure published in NATURE GENETICS since 2007.

\section{GENE-ENVIRONMENT INTERPLAY}

Thirteen years GWAS for hypertension, from the beginning "failure" to the recent "success," can we say GWASs have deciphered the genetic architecture of hypertension? The answer is obviously NO. This is because of the fact that environmental factors and gene-environment interactions are likely major contributors to the development of hypertension, however, they were largely ignored in present GWASs (Cooper, 2018).

As widely accepted, hypertension is a consequence of significant interaction between genetic and environmental factors. Here, the meaning of "environment" is extensive, including intrauterine, postnatal and evolutionary environments. It has long been known that intrauterine environmental factors (e.g., maternal nutritional perturbation, toxin exposure, and stress during pregnancy) may result in hypertension in adult life. Recent epidemiological and experimental studies further indicated that paternal environmental factors, before conception and during sperm development, were also linked to the development of hypertension in later life (Li et al., 2016). On the other hand, classic epidemiological studies have addressed many postnatal environmental risk factors for hypertension, including living environments (cold temperature, air pollution, and toxins), life styles (lack of physical activity, psychological stress, smoking, alcohol abuse, drug use, improper nutrition, excessive salt intake, and obesity), and other demographic differences in age, gender, race, socioeconomic status, etc. From an evolutionary perspective, hypertension can be viewed as a maladaptation disease caused by the discrepancy between today's lifestyles and ancient adaptive genotypes. Physiologically, many risk factors for hypertension, such as enhanced salt and water avidity and vascular contractility, were adaptive traits

\section{REFERENCES}

Berg, J. (2016). Gene-environment interplay. Science 354:15. doi: $10.1126 /$ science.aal0219

Cooper, R. (2018). Hypertension, genes, and environment: challenges for prevention and risk prediction. Circulation 137, 662-664. doi: 10.1161/CIRCULATIONAHA.117.032196

Dominiczak, A. F., and Munroe, P. B. (2010). Genome-wide association studies will unlock the genetic basis of hypertension: pro side of the argument. Hypertension 56, 1017-1020. doi: 10.1161/HYPERTENSIONAHA.110. 156208

Ehret, G. B., Ferreira, T., Chasman, D. I., Jackson, A. U., Schmidt, E. M., Johnson, T., et al. (2016). The genetics of blood pressure regulation and its target organs from association studies in 342,415 individuals. Nat. Genet. 48, 1171-1184. doi: $10.1038 /$ ng.3667 associated with salt scarcity in the hot and humid climate of the ancestral African environment. As humans migrated out of Africa to cooler environments, the originally selected genes became maladaptive for new environments and turned into risk factors for hypertension (Young et al., 2005; Ji et al., 2016).

\section{DISCUSSION}

Due to the complexity of essential hypertension, previous GWAS didn't find many robust variants. If more related factors are considered, and method like phenomics is used, future studies may help us to deeply understand this complex disease. As emphasized by Jeremy Berg, editor-in-chief of SCIENCE, genes alone do not determine our futuresenvironmental factors and chance also play important roles (Berg, 2016). Indeed, 13 years GWASs for hypertension really made a big step forward, however, if we leave behind another important factor, the environment, can also impede our progress. Incredibly, the environmental effects were ignored in almost all published GWASs of blood pressure traits or hypertension. Some studies were conducted in well-established cohorts like Global BPGen and CHARGE, and many environmental data should be available. Although analyzing the geneenvironment interaction is still a great challenge, GWASs without consideration of environmental effects will definitely not go to address the key question regarding the genetic architecture of hypertension.

\section{AUTHOR CONTRIBUTIONS}

L-dJ and JX conceived the opinion. L-dJ, NT, Z-fX, and JX wrote the manuscript. All authors contributed to the article and approved the submitted version.

\section{FUNDING}

This work was supported by the National Natural Science Foundation of China (81402747), Funding of Science and Technology on Medicine and Health in Zhejiang Province (2019KY650), as well as the K.C. Wong Magna Fund in Ningbo University.
Evangelou, E., Warren, H. R., Mosen-Ansorena, D., Mifsud, B., Pazoki, R., Gao, H., et al. (2018). Genetic analysis of over 1 million people identifies 535 new loci associated with blood pressure traits. Nat. Genet. 50, 1412-1425. doi: 10.1038/s41588-018-0205-x

Giri, A., Hellwege, J. N., Keaton, J. M., Park, J., Qiu, C., Warren, H. R., et al. (2019). Trans-ethnic association study of blood pressure determinants in over 750,000 individuals. Nat. Genet. 51, 51-62. doi: 10.1038/s41588-018-0303-9

Hoffmann, T. J., Ehret, G. B., Nandakumar, P., Ranatunga, D., Schaefer, C., Kwok, P. Y., et al. (2017). Genome-wide association analyses using electronic health records identify new loci influencing blood pressure variation. Nat. Genet. 49, 54-64. doi: 10.1038/ng.3715

Ji, L. D., Tang, N. L., and Xu, J. (2016). AGTR1 has undergone natural selection in Euro-Asian populations in relation to ambient temperature that predisposes Chinese populations to essential hypertension. Int. J. Cardiol. 209, 278-280. doi: 10.1016/j.ijcard.2016.02.031 
Kurtz, T. W. (2010). Genome-wide association studies will unlock the genetic basis of hypertension.: con side of the argument. Hypertension 56, 1021-1025. doi: 10.1161/HYPERTENSIONAHA.110. 156190

Levy, D., Ehret, G. B., Rice, K., Verwoert, G. C., Launer, L. J., Dehghan, A., et al. (2009). Genome-wide association study of blood pressure and hypertension. Nat. Genet. 41, 677-687. doi: 10.1038/ng.384

Li, J., Tsuprykov, O., Yang, X., and Hocher, B. (2016). Paternal programming of offspring cardiometabolic diseases in later life. J. Hypertens 34, 2111-2126. doi: 10.1097/HJH.00000000000 01051

Liu, C., Kraja, A. T., Smith, J. A., Brody, J. A., Franceschini, N., Bis, J. C., et al. (2016). Meta-analysis identifies common and rare variants influencing blood pressure and overlapping with metabolic trait loci. Nat. Genet. 48, 1162-1170. doi: $10.1038 /$ ng. 3660

Newton-Cheh, C., Johnson, T., Gateva, V., Tobin, M. D., Bochud, M., Coin, L., et al. (2009). Genome-wide association study identifies eight loci associated with blood pressure. Nat. Genet. 41, 666-676. doi: 10.1038/ng.361

Surendran, P., Drenos, F., Young, R., Warren, H., Cook, J. P., Manning, A. K., et al. (2016). Trans-ancestry meta-analyses identify rare and common variants associated with blood pressure and hypertension. Nat. Genet. 48, 1151-1161. doi: $10.1038 /$ ng.3654
The Wellcome Trust Case Control Consortium (2007). Genome-wide association study of 14,000 cases of seven common diseases and 3,000 shared controls. Nature 447, 661-678. doi: 10.1038/nature05911

Warren, H. R., Evangelou, E., Cabrera, C. P., Gao, H., Ren, M., Mifsud, B., et al. (2017). Genome-wide association analysis identifies novel blood pressure loci and offers biological insights into cardiovascular risk. Nat. Genet. 49, 403-415. doi: $10.1038 /$ ng.3768

Young, J. H., Chang, Y. P., Kim, J. D., Chretien, J. P., Klag, M. J., Levine, M. A., et al. (2005). Differential susceptibility to hypertension is due to selection during the out-of-Africa expansion. PLoS Genet. 1:e82. doi: 10.1371/journal.pgen.0010082

Conflict of Interest: The authors declare that the research was conducted in the absence of any commercial or financial relationships that could be construed as a potential conflict of interest.

Copyright (c) $2020 \mathrm{Ji}$, Tang, Xu and Xu. This is an open-access article distributed under the terms of the Creative Commons Attribution License (CC BY). The use, distribution or reproduction in other forums is permitted, provided the original author(s) and the copyright owner(s) are credited and that the original publication in this journal is cited, in accordance with accepted academic practice. No use, distribution or reproduction is permitted which does not comply with these terms. 